Петровська С. I., к.е.н., старший викладач

Національний транспортний університет м. Київ, Украӥна

DOI: https://doi.org/10.30525/978-9934-26-068-1-6

\title{
ВИМОГИ ДО ОЦНЮВАННЯ ЯКОСТІ ПОСЛУГИ 3 ПЕРЕВЕЗЕНЬ ПАСАЖИРІВ ТРАНСПОРТОМ ЗАГАЛЬНОГО КОРИСТУВАННЯ В МІСТІ
}

Для кожного 3 цих напрямів оцінювання якості в системі виділено на одному з трьох рівнів (складні та прості властивості якості, показники якості) набори критеріїв оцінювання. Такими критеріями на найнижчому рівні (показників) $є$ : відповідність комфортності, коефіцієнт використання місткості, динаміка коефіцієнту безпеки, рівень відмов у посадці, коефіцієнт регулярності, рівень транспортної втоми, витрати часу на поїздку, стабільність тарифів, рівень інформаційного обслуговування пасажирів, щільність маршрутної мережі.

Зробимо кілька критичних зауважень щодо такого підходу до оцінювання якості. По-перше, критерії якості часом $є$ синтетичними (наприклад, комфорт), отже вони не можуть бути показниками. По-друге, частина показників не може бути визначена лише об'єктивно, необхідно враховувати точку зору пасажира (наприклад, транспортна втома). По-третє, деякі показники взагалі не належать до вимірювачів якості (стабільність тарифів). Таким чином, бачимо намагання розробити заходи 3 поліпшення якості міських перевезень на основі даної системи, яка вже стала «класичною». Вона не враховує: особливостей географії певного міста та його транспортної інфраструктури; специфіку попиту на перевезення; ринкову ситуацію, в якій працюють перевізники; соціальні та екологічні чинники, яким має приділяти увагу міська влада. А головне - в ній лише частково відображено потреби пасажирів. Через це заходи, є лише вельми загальними напрямами зусиль менеджменту міського перевізника [3]. 
Оцінка рівня якості транспортної продукції та роботи являється окремими функціями в управління якістю. Тому дані методи кількісної оцінки можуть бути використані як підсистеми управління якістю на підприємствах. Створення та реальне функціонування системи управління якістю продукції транспортних підприємств на базі запропонованої системи показників забезпечить підвищення рівня якості транспортної продукції, що, в свою чергу, забезпечить покращення економічних показників роботи цих транспортних підприємств.

Під час розгляду проблематики якості перевезень пасажирів інші автори дотримуються схожого підходу. Різниця в тому, що Спірин І.В. використовує термін «якість транспортного обслуговування» [1], а Гудков В.А. зі співавторами - «якість перевезень пасажирів» або «якість транспортних послуг» [2]. Обидва джерела стверджують, що якість є комплексною властивістю, але зміст іiі наповнення окремими складовими в авторів різниться. Відмінними $є$ й підходи до синтезу агрегованих показників якості.

Проте це не заважає запропонувати власну точку зору й представити іiі на рис. 1. Зауважимо, що на рис. 1 в частині прямокутників приведено не показники вимірювання якості, а лише напрями для їх конструювання. Наприклад, зручність сидінь можна оцінити з огляду на середні розміри тіла дорослої людини в термінах відстаней і розмірів, але іï ж можна виміряти i 3 точки зору окремого пасажира в номінальній (зручно або ні) порядковій (наприклад, Р. Лікерта) або інтервальній (4 бали з 5) шкалах.

Наступною важливою особливістю вимірювань якості перевезень міським транспортом $\epsilon$ необхідність враховувати різницю між їх наданою перевізником та сприйнятою пасажиром якістю. Точкова оцінка такої різниці здатна давати інформацію щодо вектору поліпшень якості, але вона не $є$ достатньою для управління нею. Перевірка успішності управлінського впливу на якість стає можливою, коли такі вимірювання проводяться у вигляді моніторингу. 


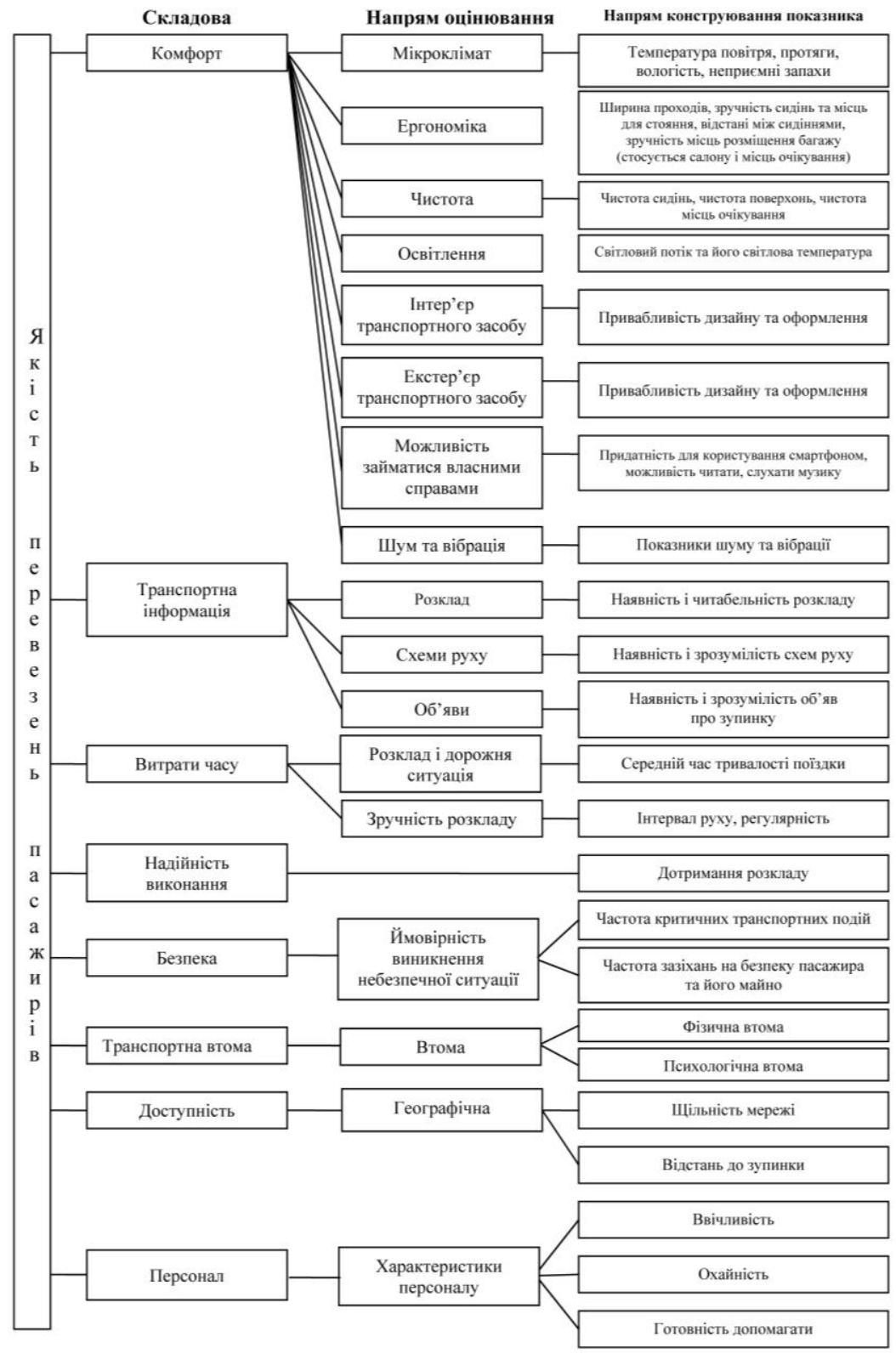

Рис. 1. Зміст оцінювання якості перевезень пасажирів транспортом загального користування в місті 
Сформулюємо комплекс вимог і застережень до проведення моніторингу якості послуг міського транспорту.

1. Винятковість важливості якості як чинника поведінки пасажира міського транспорту. Якість послуг транспорту загального користування в місті $\epsilon$ головним чинником транспортної поведінки i попиту на перевезення, a для переключення користувачів приватних автомобілів - єдиним чинником. Це дозволяє суттєво спростити конструювання дизайну досліджень.

2. Мінливість змісту якості. Набір показників якості, які підлягають моніторингу, залежить від виду транспорту. Так, роботу метрополітену не варто оцінювати за часом очікування транспортного засобу. А клаустрофобія не $\epsilon$ важливим чинником відмови від поїздок у салоні тролейбуса.

3. Пріоритет визначення місця i часу контролю якості. На маршрутах 3 напруженим пасажиропотоком слід приділяти більшу увагу якості перевезень.

4. Залежність якості від частоти користування. Оцінка якості перевезень пасажиром залежить від частоти користування.

5. Періодична основа вимірювань. Вимірювання якості перевезень мають здійснюватися на періодичній основі, тоді менеджери перевізника матимуть повну інформацію щодо управління якістю транспортної послуги.

6. Урахування інтересів суб'єктів перевезень. Оцінюванню підлягає як надана перевізником (нормативна), так і сприйнята пасажиром якість.

7. Адаптивність інструментарію. Інструментарій оцінювання має адаптуватись під зміну цілі досліджень та (або) під зміну умов їі досягнення.

Отже, вимоги і застереження до оцінювання якості послуги 3 перевезень пасажирів транспортом загального користування в місті $\epsilon$ такими: транспортний сервіс, як головний чинник поведінки пасажира, має виняткову природу, зміст транспортної послуги є мінливим, необхідно ретельно визначати місце i часовий момент контролю якості, якість транспортної послуги 
залежить від частоти користування, вимірювання якості мають проводитись на періодичній основі, мають враховуватись інтереси всіх суб'єктів перевезень, інструментарій повинен обиратися з огляду на завдання оцінювання.

\section{Література:}

1. Гудков В.А. Качество пассажирских перевозок: возможность исследования методами социологии. Волгоград : ВолгГТУ, 2008. 163 с.

2. Спирин И.В. Перевозки пассажиров городским транспортом: Справочное пособие. Москва : Академкнига. 2002. 448 с.

3. Петровська С.I. Економічне обгрунтування ефективності пасажирських перевезень. Вісник Національного транспортного університету: науковотехнічний збірник. Київ : НТУ, 2011. Вип. 21 (1). С. 412-417. 